\title{
How Dermoscopy Shows Gunshot Accident: A Patient with Post- Traumatic Tattoo by Plomb Mishaps Products
}

\author{
Dahhouki S*, Issoual K, Jroundi C, Douhi Z, Elloudi S, Baybay H, Mernissi FZ \\ Hassan II hospitalier university, Morocco \\ Case Report \\ Volume 5 Issue 2 \\ Received Date: March 16, 2020 \\ *Corresponding author: Dr. Sara Dahhouki, Hassan II hospitalier university, 590 Lot Ouafae IV, \\ Sefrou Roed, FezMorocco, Tel: +212690962726; Email: dahhoukisara@gmail.com \\ Published Date: April 01, 2020 \\ DOI: $10.23880 /$ cdoaj-16000209
}

\section{Abstract}

Gunshot accident can cause ulceration. Traumatic tattoos result from inclusions of intradermal plomb mishaps particles. Our article highlights the clinical and dermoscopic signs in a patient victim of this accident.

Keywords: Dermoscopy; Plomb mishaps products; Tattoo

\section{Case Report}

63-year-old patient, victim of a gunshot accident at age 19, following which, he has kept a post-traumatic tattoo by plomb mishaps products on the forehead and suborbital area, consulted for persistent pigmented skin lesions. Dermatological examination had noted multiple grayishblue pigmented papules on the forehead and suborbital area. Dermoscopy shows a homogeneous grayish-blue pigment, shiny white areas and grayish-white blotches and strands which formed grayish-blue veil. Giving the risk of sparking due to gunpowder residue, laser treatment was no longer an option, so incision and extraction was done.

Blast type injuries seen in military casualties and civilian powder burns, as well as firework, and blomb mishaps products, un-ignited gunpowder, and other foreign materiel that act like hundreds small missiles, each penetrating the wound to various depths [1]. Although there are multiplicities of techniques to treat traumatic tattoo, no one is perfect. The treatment options include surgical excision, dermabrasion, cryosurgery, electro surgery and laser, such as, carbon dioxide argon, Q-swiched, Nd:YAG, and erbium Nd:YAG. A note of caution is in order when treating gunpowder during laser tattoo removal, resulting in spreading of the tattoo or creation of significant dermal pits [2]. As note caution, rapid removal of particles, by irrigation and rubbing, is much more effective than subsequent removal, because once the skin has healed, treatment becomes unresolved problem [3]. With our case, we would like to highlight the importance of early intervention in case of a trauma to prevent deep and permanent tattoos.

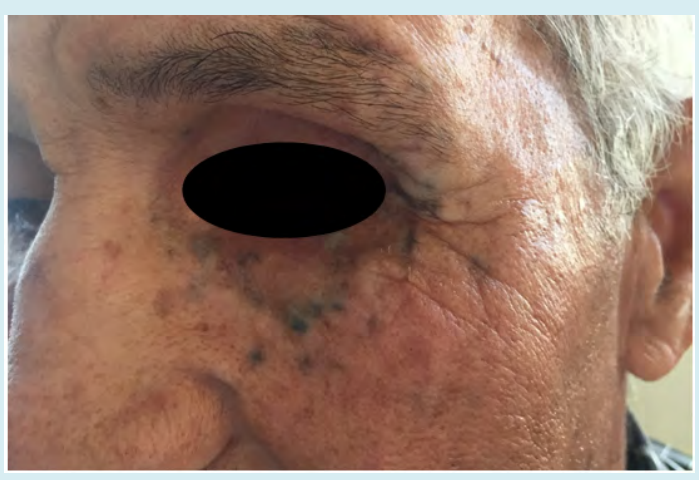

Figure 1: Multiple greyish-blue pigmented papules on suborbital area. 


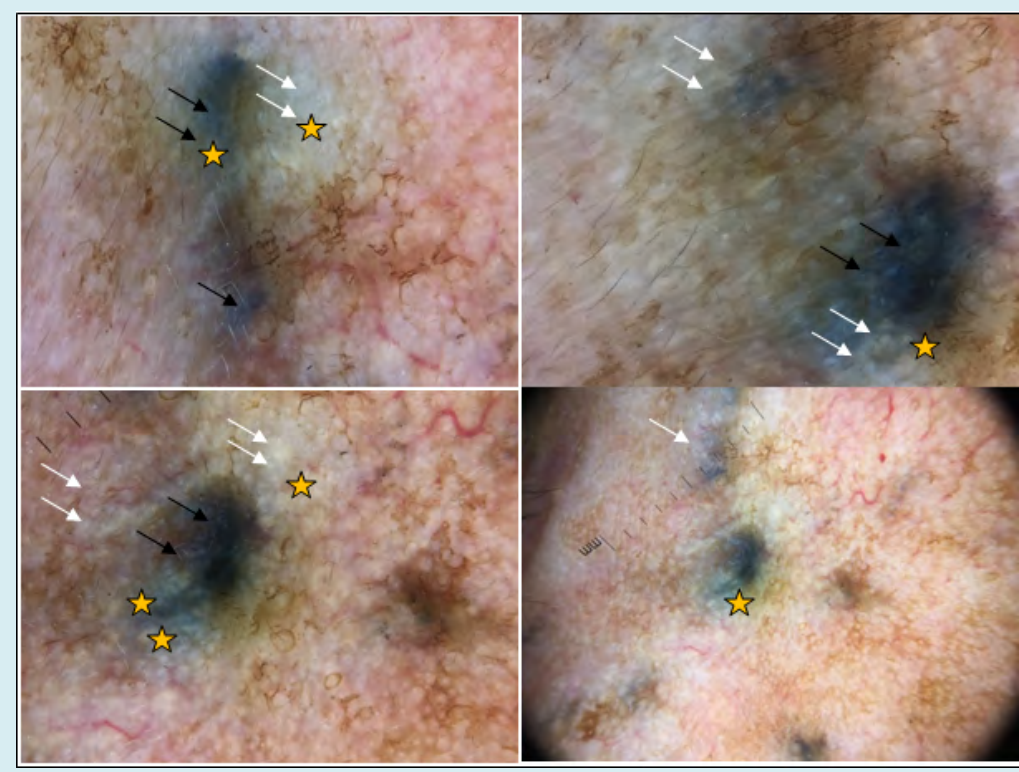

Figure 2: Dermoscopy shows a homogeneous grayish-blue pigment (dark narrows), shiny white areas, grayish-white blotches and strands (white narrows) which formed grayish-white veil (yellow stars).

\section{References}

1. Baruchin AM, Schaf S (1992) Care of traumatic tattoos associated with gunpowder explosions and blast burns. The Management of Mass Burn Casualties and Fire Disasters. Springer, Dordrecht, pp: 292-295.

2. Eduardo D Rodriguez, Joseph E Losee, Peter C Neligan
(2012) Plastic Surgery. $3^{\text {rd }}$ (Vol.), Craniofacial, Head and Neck Surgery Pediatric Plastic Surgery. Elsevier Health Sciences.

3. Christa de Cuyper, Maria Luisa Cotapos (2009) Dermatologic complications with body art: tattoos, piercings and permanent make-up. Springer Science \& Business Media, pp: 103. 